\title{
Robert Edward Gross (1905-1988): ligation of a patent ductus arteriosus and the birth of a specialty.
}

\author{
Alexander V. Chalphin, BS \\ Thomas Jefferson University \\ Charles J. Yeo, MD \\ Thomas Jefferson University \\ Scott W. Cowan, MD \\ Thomas Jefferson University \\ Stacey Milan, MD \\ Thomas Jefferson University
}

Follow this and additional works at: https://jdc.jefferson.edu/gibbonsocietyprofiles

Part of the History of Science, Technology, and Medicine Commons, and the Surgery Commons Let us know how access to this document benefits you

\section{Recommended Citation}

Chalphin, BS, Alexander V.; Yeo, MD, Charles J.; Cowan, MD, Scott W.; and Milan, MD, Stacey, "Robert Edward Gross (1905-1988): ligation of a patent ductus arteriosus and the birth of a specialty." (2014). Department of Surgery Gibbon Society Historical Profiles. Paper 25.

https://jdc.jefferson.edu/gibbonsocietyprofiles/25

This Article is brought to you for free and open access by the Jefferson Digital Commons. The Jefferson Digital Commons is a service of Thomas Jefferson University's Center for Teaching and Learning (CTL). The Commons is a showcase for Jefferson books and journals, peer-reviewed scholarly publications, unique historical collections from the University archives, and teaching tools. The Jefferson Digital Commons allows researchers and interested readers anywhere in the world to learn about and keep up to date with Jefferson scholarship. This article has been accepted for inclusion in Department of Surgery Gibbon Society Historical Profiles by an authorized administrator of the Jefferson Digital Commons. For more information, please contact: JeffersonDigitalCommons@jefferson.edu. 


\title{
Robert Edward Gross (1905-1988): Ligation of a Patent Ductus Arteriosus and the Birth of a Specialty
}

ALEXANDER V. CHALPHIN, B.S., CHARLES J. YEO, M.D., SCOTT W. COWAN, M.D., STACEY MILAN, M.D.

\begin{abstract}
From the Department of Surgery, Thomas Jefferson University, Jefferson Medical College, Philadelphia, Pennsylvania
\end{abstract}

$\mathrm{T}$ HE EARLY 20TH century saw an explosion in surgical expertise. Specialties dedicated to delicate organs such as the heart and vulnerable populations, like children, were in their infancy. Dr. William E. Ladd, the father of pediatric surgery, founded the first dedicated department of pediatric surgery at Boston Children's Hospital in 1910. At the time, attempts at cardiac surgery almost universally ended in death of the patient. The first successful surgical treatment of the cardiac valves would not occur for another 15 years, and the great vessels would remain out of reach for decades more. Dr. Robert E. Gross, the shy and humble heir to the greats of this epoch, would push these embryonic fields into the modern era and train a generation of surgeons to face countless new challenges (Fig. 1).

Robert Edward Gross was born in Baltimore, Maryland, on July 2, 1905, the seventh of Charles Jacob and Emma Houch Gross' eight children. As a child, the young Gross determined, by looking at his finger and closing one eye at a time, that he had no sight in one of his eyes. His father, a Baltimore piano maker, gave his son a series of clocks to take apart and reassemble, hoping that the activity would help his son develop the depth perception and fine motor skills necessary for a future career in manufacturing pianos. Gross kept his disability secret for the entirety of his career, only divulging his condition in an effort to encourage a former resident who had lost an eye to melanoma. Gross' congenital cataract was not removed until long after he had retired. Although many were shocked that Gross was able to succeed despite his disability, the fact that the meticulous, soft-spoken surgeon would keep such a condition to himself surprised no one. ${ }^{1}$

An avid outdoorsman, Gross attended Carleton College in Minnesota, in large part because of how much he enjoyed spending his childhood summers at

Address correspondence and reprint requests to Scott W. Cowan, M.D., Department of Surgery, Thomas Jefferson University, 1100 Walnut Street, $5^{\text {th }}$ Floor, Philadelphia, PA 19107. E-mail: Scott. Cowan@Jefferson.edu. work on a Minnesota farm. There he met and wed Mary Lou Orr, the daughter of a surgeon. Gross' initial academic pursuit was chemistry, but receiving Harvey Cushing's biography of Sir William Osler forever changed his professional trajectory. The story of Dr. Osler's life fascinated the young student, and in 1927, he entered Harvard Medical School. ${ }^{2}$

Gross thrived at Harvard, and a brief rotation in his fourth year on Dr. William Ladd's surgical service offered him his first glimpse into his future specialty. After graduation, Gross began training in pathology at Boston Children's with Dr. Burt Wolbach, who would quickly become not only a mentor, but also one of Gross' closest friends. It was during his training in pathology that Gross became intimately familiar with the phenomenon of the patent ductus arteriosus (PDA) while performing pediatric autopsies. After 2 years in pathology, Gross began surgical training under Ladd, still at Boston Children's. In 1937, before beginning his final year of residency, Gross spent 9 months traveling around Europe as Harvard's George Gorham Peter's Traveling Fellow. The tour took the young surgeon to some of the greatest surgical centers of the continent, including the Royal Hospital for Sick Children in Edinburgh, an experience that made a lasting impression on him. ${ }^{3}$

Robert Gross returned to Boston in 1938 and began his chief residency under Dr. William Ladd and Dr. John Hubbard. With his experience in Edinburgh

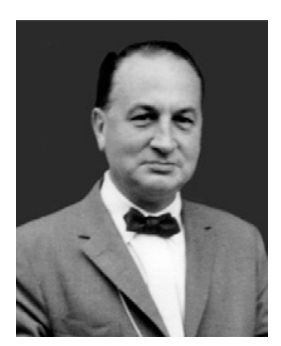

FIG. 1. Reproduced from the Harvard Office of for Faculty Affairs, Harvard Medical School and Harvard School of Dental Medicine. Available at: www.fa.hms.harvard.edu/about-our-faculty/ memorial-minutes/g/robert-e-gross/. Accessed March 4, 2013. 
still fresh in his mind, Gross began research into congenital cardiovascular malformations with Hubbard. After spending hours in the cadaver laboratory, Gross and Hubbard determined that surgical ligation of a PDA, a common malformation that often doomed children to heart failure and early death, might be feasible. In August of 1938, while Ladd was on vacation in Europe, the young chief resident got permission from the acting chief, Dr. Thomas Lanman, to attempt the ligation of a PDA in a 7-year-old girl. The procedure was a resounding success, and the girl was discharged 10 days later. ${ }^{1}$

The daring procedure won Gross instant acclaim from the surgical community with the notable exception of Gross' superior, Dr. William E. Ladd. The father of pediatric surgery never forgave his protégé for performing the landmark operation in his absence, and Gross never apologized for doing a procedure that he thought Ladd would never have agreed to had he been present. After Ladd retired, Gross was the natural candidate to fill the vacant chair of pediatric surgery, but Ladd held up the nomination for a full 2 years before the Board of Trustees went against the retired doctor's wishes and appointed Gross to the post. ${ }^{2}$

Recently, alternative accounts have come to light suggesting that Robert E. Gross may not have been the first to perform a successful PDA ligation. Late in 1937 or early in 1938, Dr. Emil Karl Frey of Dusseldorf, Germany, performed a PDA ligation in a 14-year-old boy, who went on to survive the operation. The boy had previously been misdiagnosed and undergone surgery for what had been thought to be a left-sided intrathoracic arteriovenous fistula. Frey planned on publishing his account of the case after performing another PDA ligation in a patient who did not have a confounding previous surgery. Unfortunately, the start of World War II prevented the German physician from performing the subsequent operation or publishing his account. All documentation of the procedure was later destroyed in the allied bombings of Dusseldorf, and it is likely that we will never know for certain which surgeon truly performed the first PDA ligation. ${ }^{4}$

Regardless of which surgeon was the first to ligate a PDA, Gross went on to achieve many more "firsts."
In 1948 he became the first to graft arterial tissue from one patient to another in the treatment of coarctation of the aorta, which constituted an enormous breakthrough in both pediatric and vascular surgery. Gross became one of the most decorated surgeons of his age. He won the Albert Lasker award in 1954 and again in 1956 along with 26 other medals from various organizations. In 1953 Gross published what would become one of the definitive textbooks of his field, The Surgery of Infancy and Childhood, which numbered exactly 1000 pages. The first edition famously failed to include a chapter on sacrococcygeal teratoma, an omission that Gross claimed to be an honest error. Others have speculated it was purposefully done to keep the text at a round page number. He was a founding member of the American Board of Surgery and the American Board of Thoracic Surgery, and he served as the president of both bodies. $^{3}$

Dr. Robert E. Gross retired in 1972 and resettled in Brattleboro, Vermont. The prolific surgeon had suffered from lumbar and sciatic problems for years and in his last decade of life, he underwent multiple laminectomies. He recovered from the operations well, and he was known for his constant, encouraging correspondence with the ranks of residents he had trained over the course of his career. Indeed, 20 of the 43 programs for pediatric surgery in the United States can directly trace their academic lineage to Gross. He died quietly from Alzheimer's disease on October 11, 1988, not only survived by his two daughters, but also legions of grateful students and patients. $^{2}$

\section{REFERENCES}

1. Clatworthy HW. Robert E. Gross. Prog Pediatr Surg 1986;20:76-84.

2. Fisher JC, Hardy MA, Widman WD. Robert E. Gross: the heart of a surgeon. Curr Surg 2005;62:495-9.

3. Moore FD, Folkman J. Robert Edward Gross-July 2, 1905-October 11, 1988. Biogr Mem Natl Acad Sci 1995;66: 131-48.

4. Kaemmerer H, Meisner H, Hess J, Perloff JK. Surgical treatment of patent ductus arteriosus: a new historical perspective. Am J Cardiol 2004;94:1153-4. 